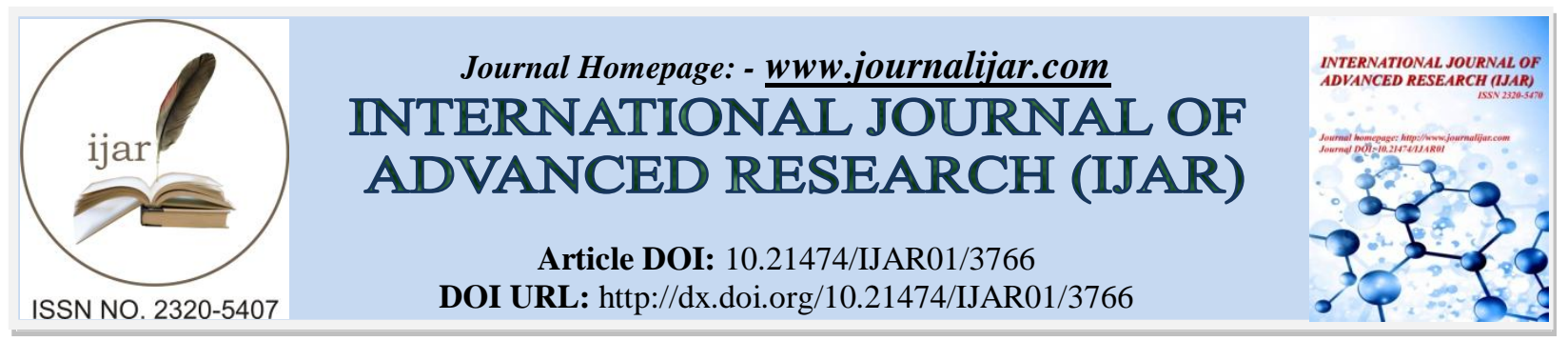

RESEARCH ARTICLE

\title{
STUDY ON THE BACTERIAL ISOLATES FROM HAND SWAB SAMPLES OF HEALTH CARE WORKERS AND ANTI-BIOTIC SENSITIVITY PATTERN, IN A TERTIARY CARE HOSPITAL, LUCKNOW
}

\author{
Kumari D, Khare V, Yaqoob S, Shukla P, Haider F and Singh M.
}

\section{Manuscript Info}

Manuscript History

Received: 17 January 2017

Final Accepted: 02 February 2017

Published: March 2017

\section{Abstract}

Copy Right, IJAR, 2017,. All rights reserved.

\section{Introduction:-}

The contaminated hands of health care workers (HCW),play an important role in transmission of hospital infection, and is a common pattern seeing in most healthcare settings[1]. An important cause of morbidity and mortality among hospitalized patients worldwide, is Healthcare-associated infections (HCAIS), also known as nosocomial infections[2]. In developed countries, HCAIs have been reported to affect 5\%-15\% of hospitalized patients and 9\%$37 \%$ of those admitted to intensive care units (ICUs), while in developing countries, prevalence rates have been estimated to be between $14.8 \%$ and $19.1 \%$ [3]. The single most important measure to prevent cross-transmission of microorganisms and to reduce the rate of nosocomial infection is to maintain hand hygiene[4]. The landmark study carried out by Semmelweis in 1884 , demonstrated that the simple act of hand washing could save lives especially when health care workers do it routinely and thoroughly[5]. The organisms transmitted can be harmful for both patients and health-care workers, and these organisms are sometimes resistant to antimicrobial agents (AMA) .Still, health-care workers(HCW), do not practice hand washing[6].

To reduce such infections in hospital, a targeted surveillance culture to identify asymptomatic carriers of multidrug resistant bacteria and subsequent isolation and treatment should be done. To predict possible risk of infection with multi-drug resistant bacteria in health-care settings, the sensitivity patterns of isolates should also be studied.

This study was therefore undertaken in a TERTIARY CARE HOSPITAL, LUCKNOW as part of a wide scale hospital infection control surveillance programme. It seeks to ascertain the proportion of bacterial colonization of the isolates from the hands of healthcare workers who are in regular contact with patients, and to determine multidrug resistant isolates for possible intervention.

\section{Materials and Methods:-}

This study was carried out in Era's Lucknow Medical College \& Hospital, Lucknow, which is a tertiary care hospital, in the month of August 2015. Ethical clearance was taken from the Institutional Ethics Committee.

A total of 60 hand swab samples were collected from 60 healthcare workers of the Hospital. Of all the healthcare workers, $50(83.3 \%)$ were female nurses and $10(16.7 \%)$ were male nurses, which were choosen randomly. Sterile cotton wool swabs, which were pre- moistened in sterile normal saline, were used to swab the interdigital spaces, dorsal and ventral aspect of hands of the participants. The media used in this study were Blood Agar, MacConkey 
Agar and Mueller Hinton Agar. The swabs from hands were cultured on Blood agar and MacConkey agar plates. The plates were incubated at $35^{\circ} \mathrm{C}$ for $24-48 \mathrm{hrs}$. The bacterial isolates were identified using bacteriological procedures, involving microscopy, morphology, and biochemical tests.

All detected bacterial isolates were tested for antimicrobial susceptibility test by the standard Kirby-Bauer disc diffusion method, according to the Clinical Laboratory Standard Institute (CLSI) guidelines. The test organism was picked up with a sterile loop, suspended in peptone water and incubated at $37^{\circ} \mathrm{C}$ for $2 \mathrm{~h}$. The turbidity of the suspension was adjusted to $0.5 \mathrm{McFarland}$ 's standard. It was then spread on the surface of Mueller-Hinton Agar (MHA) plate using sterile cotton swab. After drying the plates $\left(37^{\circ} \mathrm{C}\right.$ for 30 minutes) antibiotic discs were applied by sterile forceps. Staphylococcus aureus ATTC 25923 and Escherichia coli ATTC 25922, P. aeruginosa ATCC 27853 were used as controls during the study.

\section{Results:-}

A total 60 hand swab sample, were collected from 60 healthcare workers of Era's Lucknow Medical College \& Hospital, Lucknow, among which 50 (83.3\%) were female nurses and 10(16.7\%) were male nurses. Of the 60 samples analysed, 48 (80\%) yielded bacterial growth, while $12(20 \%)$ showed no bacterial growth. Out of the 48 isolates, $36(75 \%)$ were Gram negative, and 12(25\%) were Gram positive organisms. Also out of total $50(83.3$ $\%)$ females nurses, $30(60 \%)$ had Gram negative and $8(16 \%)$ had gram positive bacteria; while out of $10(16.7$ $\%$ )male nurses, 6( 60\%) had Gram negative and 4 ( 40\%) had Gram positive bacteria.(Table1)

\begin{tabular}{|l|l|l|}
\hline TOTAL NO. $(\%)$ & TOTAL GRAM NEGATIVE & TOTAL GRAM POSITIVE \\
\hline FEMALE NURSES- 50 (83.3) & $30(60 \%)$ & $8(16 \%)$ \\
\hline MALE NURSES $-10(16.7)$ & $6(60 \%)$ & $4(40 \%)$ \\
\hline
\end{tabular}

TABLE 1:- ( Distribution of Gram negative and Gram positive bacteria among female and male nurses)

Also out of total 38 bacterial isolates in female nurses,30(78.9\%) were Gram negative and $8(21.05 \%)$ were gram positive bacteria ; while out of 10 bacterial isolates in male nurses, $6(60 \%)$ were Gram negative and 4 (40\%) Gram positive bacteria.(Table 2)

\begin{tabular}{|l|l|l|l|l|}
\hline SOURCE & & $\begin{array}{l}\text { TOTAL NMBER } \\
\text { OF ISOLATES }\end{array}$ & GRAM NEGATIVE & GRAM POSITIVE \\
\hline HAND SWABS & FEMALE NURSES & 38 & $30(78.9 \%)$ & $8(21.05 \%)$ \\
\hline & MALE NURSES & 10 & $6(60 \%)$ & $4(40 \%)$ \\
\hline
\end{tabular}

TABLE 2:- (Distribution of Bacteria among nurses, out of total bacterias isolated)

Of the 60 samples analyzed, bacterial isolates were seen in 48. Out of total 48, organisms were identified as 22( 45.8\%) Escherichia coli, 4(8.3 \%) Pseudomonas aeruginosa ,10(20.8\%) Klebsiella pneumoniae and 12 as Staphylococcus spp, of which 8(16.6\%) were Staphylococcus aureus and 4 ( $8.3 \%)$ wereCoagulase Negative Staphylococcus(CONS).(Table 3)

\begin{tabular}{|l|l|}
\hline TOTAL BACTERIAL ISOLATES & 48 \\
\hline Escherichia coli & $22(45.8 \%)$ \\
\hline Pseudomonas aeruginosa & $4(8.3 \%)$ \\
\hline Klebsiella pneumoniae & $10(20.8 \%)$ \\
\hline Staphylococcus aureus & $8(16.6 \%)$ \\
\hline CONS & $4(8.3 \%)$ \\
\hline
\end{tabular}

Table 3- Different bacterias isolated in the study

Out of 22( $45.8 \%)$ Escherichia coli isolated, 20(90.9\%)were in female nurses and 2(9.1\%)were in male nurses.

Out of 4( $8.3 \%)$ Pseudomonas aeruginosa, all the 4(100\%)were in female nurses and none was found in male nurse $0(0 \%)$.

Out of 10( $20.8 \%)$ Klebsiella pneumoniae,6(60\%)were in female nurses and 4(40\%) were in male nurses.

12were Staphylococcus spp, of which 8(16.6\%) were Staphylococcus aureus and 4 ( $8.3 \%)$ were CONS.

Out of $8(16.6 \%)$ Staphylococcus aureus, 6(75\%) were in female nurse and 2(25\%) in male nurses.

Out of $4(8.3 \%)$ CONS, 2(50\%) were in female nurses and 2(50\%) were in male nurses. (Table 4$)$ 


\begin{tabular}{|l|l|l|}
\hline ORGANISMS & $\begin{array}{l}\text { ORGANISMS FOUND IN } \\
\text { FEMALE NURSES }\end{array}$ & $\begin{array}{l}\text { ORGANISMS FOUND IN } \\
\text { MALE NURSES }\end{array}$ \\
\hline ESCHERICHIA COLI 22(45.8\%) & $20(90.9 \%)$ & $2(9.1 \%)$ \\
\hline PSEUDOMONAS AERUGINOSA 4(8.3\%) & $4(100 \%)$ & $0(0 \%)$ \\
\hline KLEBSIELLA PNEUMONIAE 10(20.8\%) & $6(60 \%)$ & $4(40 \%)$ \\
\hline STAPHYLOCOCCUS AUREUS $8(16.6 \%)$ & $6(75 \%)$ & $2(25 \%)$ \\
\hline CONS4(8.3\%) & $2(50 \%)$ & $2(50 \%)$ \\
\hline
\end{tabular}

Table 4- Distribution of total Bacteria isolated among female and male nurses

Out of total 50(83.3\%) female nurses, Escherichia coli were isolated from 20(40\%) female nurses, Pseudomanas aeruginosa were isolated from 4(8\%) female nurses, Klebsiella pneumoniae were isolated from 6( $12 \%)$ female nurses; and Staphlococcus spp were isolated from $8(16 \%)$ female nurses ; of which 6(75\%) were Staphylococcus aureus and 2( $25 \%)$ were CONS.

Out of total 10(16.7\%) male nurses, Escherichia coli were isolated from 2(20 \%) male nurses, Pseudomanas aeruginosa were isolated from 0( 0\%) male nurse, Klebsiella pneumoniae were isolated from 4( $40 \%$ ) male nurses; again, Staphylococcus spp were isolated 4(40\%) male nurses; of which 2(50\%) was Staphylococcus aureus and $2(50 \%)$ was CONS.(Table 5).

\begin{tabular}{|c|c|c|c|c|c|c|}
\hline $\begin{array}{l}\text { TOTAL } \\
\text { FEMALE } \\
\text { NURSES } \\
50(83.3 \%)\end{array}$ & $\begin{array}{l}\text { ESCHERICHIA } \\
\text { COLI } \\
20(40 \%)\end{array}$ & $\begin{array}{l}\text { PSEUDOMONAS } \\
\text { AERUGINOSA } \\
4(8 \%)\end{array}$ & $\begin{array}{l}\text { KLEBSIELLA } \\
\text { PNEUMONIAE } \\
6(12 \%)\end{array}$ & $\begin{array}{l}\text { STAPHYLOC } \\
\text { AUREUS } \\
\\
6(75 \%), \text { OUT } \\
8(16 \%)\end{array}$ & OF & $\begin{array}{l}\text { CONS } \\
\text { 2(25\%),OUT } \\
\text { OF 8(16\%) }\end{array}$ \\
\hline $\begin{array}{l}\text { TOTAL } \\
\text { MALE } \\
\text { NURSES } \\
10(16.7 \%)\end{array}$ & $2(20 \%)$ & $0(0 \%)$ & $4(40 \%)$ & $\begin{array}{l}2(50 \%), \text { OUT } \\
4(40 \%)\end{array}$ & $\mathrm{OF}$ & $\begin{array}{l}2(50 \%), \text { OUT } \\
\text { OF } 4(40 \%)\end{array}$ \\
\hline
\end{tabular}

Table 5- Distribution of bacterial isolates among total female and male nurses

The proportion of gram negative bacteria was high 36(75\%), when compared to gram positive bacteria $12(25 \%)$,out of total 48 isolates. The antibiotic sensitivity pattern were as follows:-

Escherichia coli showed 100\% sensitivity to Ciprofloxacin, Doxycycline, Amikacin, Gentamycin, Levofloxacin ;but were resistant to Amoxycillin/ clavulanic acid(81.8\%), Ceftriaxone(72.7\%)and Co-Trimoxazole(63.6\%).Total ESBL producers were $72.72 \%$.

Pseudomonas aeruginosa showed $100 \%$ sensitivity to Ciprofloxacin, Levofloxacin, Piperacillin/Tazobactam, Imipenem; but were resistant to Ceftazidime(75\%), Cefepime(50\%), Gentamycin(25\%), Cefotaxime(75\%).

Klebsiella Pneumoniae showed 100\% sensitivity to Ciprofloxacin, Doxycycline, Amikacin, Gentamycin, Levofloxacin ; but were resistant to Amoxycillin/ clavulanic acid(60\%), Ceftriaxone(60\%) and CoTrimoxazole(50\%).Total ESBL producers were $60 \%$.

Staphylococcus aureus showed $100 \%$ sensitivity toAmikacin; but were resistant to Cefoxitin, Levofloxacin(12.5\%) ,Amoxycillin/ clavulanic acid (25\%),Ceftriaxone(62.5\%),Clindamyin(25\%),Erythromycin(50\%),Ciproflaxacin(50\%). Total MRSA was $12.5 \%$. CONS showed 100\% sensitivity to Cefoxitin, Levofloxacin, Amikacin; but were resistant to Amoxycillin/ clavulanic acid

(25\%),Ceftriaxone(75\%),Clindamyin(25\%),Erythromycin(50\%),Ciproflaxacin(50\%). All of the CONS were Methicillin susceptible.(Table 6,7,8). 


\begin{tabular}{|c|c|c|c|c|c|c|c|c|c|c|c|c|c|}
\hline $\begin{array}{l}\text { ORGANI } \\
\text { SMS }\end{array}$ & AMC & CIP & DO & AK & G & LE & $\begin{array}{l}\text { CT } \\
\text { R }\end{array}$ & $\begin{array}{l}\mathrm{CO} \\
\mathrm{T}\end{array}$ & $\begin{array}{l}\text { CA } \\
\text { Z }\end{array}$ & $\begin{array}{l}\text { CP } \\
M\end{array}$ & PIT & IPM & $\begin{array}{l}\text { CT } \\
X\end{array}$ \\
\hline $\begin{array}{l}\text { ESCHERI } \\
\text { CHIA } \\
\text { COLI- } \\
22(45.8 \%)\end{array}$ & $\begin{array}{l}4(18.1 \\
8 \%)\end{array}$ & $\begin{array}{l}22(10 \\
0 \%)\end{array}$ & $\begin{array}{l}22(10 \\
0 \%)\end{array}$ & $\begin{array}{l}22(10 \\
0 \%)\end{array}$ & $\begin{array}{l}22(10 \\
0 \%)\end{array}$ & $\begin{array}{l}22(10 \\
0 \%)\end{array}$ & $\begin{array}{l}6(27 \\
27 \% \\
)\end{array}$ & $\begin{array}{l}8(36 \\
36 \% \\
)\end{array}$ & & & & & \\
\hline $\begin{array}{l}\text { PSEUDO } \\
\text { MONAS } \\
\text { AERUGIN } \\
\text { OSA- } \\
4(8.3 \%)\end{array}$ & & $\begin{array}{l}4(100 \\
\%)\end{array}$ & & & $\begin{array}{l}3(75 \\
\%)\end{array}$ & $\begin{array}{l}4(100 \\
\%)\end{array}$ & & & $\begin{array}{l}1(25 \\
\%)\end{array}$ & $\begin{array}{l}2(50 \\
\%)\end{array}$ & $\begin{array}{l}4(10 \\
0 \%)\end{array}$ & $\begin{array}{l}4(10 \\
0 \%)\end{array}$ & $\begin{array}{l}1(25 \\
\%)\end{array}$ \\
\hline $\begin{array}{l}\text { KLEBSIE } \\
\text { LLA } \\
\text { PNEUMO } \\
\text { NIAE- } \\
10(20.8 \%)\end{array}$ & $\begin{array}{l}4(40 \\
\%)\end{array}$ & $\begin{array}{l}10(10 \\
0 \%)\end{array}$ & $\begin{array}{l}10(10 \\
0 \%)\end{array}$ & $\begin{array}{l}10(10 \\
0 \%)\end{array}$ & $\begin{array}{l}10(10 \\
0 \%)\end{array}$ & $\begin{array}{l}10(10 \\
0 \%)\end{array}$ & $\begin{array}{l}4(40 \\
\%)\end{array}$ & $\begin{array}{l}5(50 \\
\%)\end{array}$ & & & & & \\
\hline
\end{tabular}

Table:6- Antibiotic Sensitivity Pattern Of Gram Negative Bacteria

\begin{tabular}{|l|l|l|l|l|l|l|l|l|}
\hline ORGANISMS & AMC & CIP & AK & LE & CTR & CX & CD & E \\
\hline $\begin{array}{l}\text { STAPHYLOCOCCUS } \\
\text { AUREUS- } 8(16.6 \%)\end{array}$ & $6(75 \%)$ & $4(50 \%)$ & $8(100 \%)$ & $7(87.5 \%)$ & $3(37.5 \%)$ & $7(87.5 \%)$ & $6(75 \%)$ & $4(50 \%)$ \\
\hline CONS- $4(8.3 \%)$ & $3(75 \%)$ & $2(50 \%)$ & $4(100 \%)$ & $4(100 \%)$ & $1(25 \%)$ & $4(100 \%)$ & $3(75 \%)$ & $2(50 \%)$ \\
\hline
\end{tabular}

Table : 7- Antibiotic Sensitivity Pattern Of Gram Positive Bacteria

\begin{tabular}{|c|c|c|c|c|c|c|c|c|c|c|c|c|c|c|c|c|}
\hline $\begin{array}{l}\text { ORGANI } \\
\text { SMS }\end{array}$ & $\begin{array}{l}\text { AM } \\
\text { C }\end{array}$ & CIP & $\mathrm{DO}$ & $\mathrm{AK}$ & $\mathrm{G}$ & LE & $\begin{array}{l}\mathrm{CT} \\
\mathrm{R}\end{array}$ & $\begin{array}{l}\mathrm{C} \\
\text { OT }\end{array}$ & $\begin{array}{l}\mathrm{C} \\
\mathrm{AZ}\end{array}$ & $\begin{array}{l}\text { CP } \\
\text { M }\end{array}$ & PIT & $\begin{array}{l}\text { IP } \\
\text { M }\end{array}$ & $\begin{array}{l}\text { CT } \\
\mathrm{X}\end{array}$ & CX & $\begin{array}{l}\text { C } \\
\text { D }\end{array}$ & E \\
\hline $\begin{array}{l}\text { ESCHER } \\
\text { ICHIA } \\
\text { COLI- } \\
22(45.8 \% \\
)\end{array}$ & $\begin{array}{l}4(18 \\
.18 \\
\%)\end{array}$ & $\begin{array}{l}22( \\
100 \\
\%)\end{array}$ & $\begin{array}{l}22( \\
100 \\
\%)\end{array}$ & $\begin{array}{l}22( \\
100 \\
\%)\end{array}$ & $\begin{array}{l}22( \\
100 \\
\%)\end{array}$ & $\begin{array}{l}22( \\
100 \\
\%)\end{array}$ & $\begin{array}{l}6(2 \\
7 . \\
27 \\
\%)\end{array}$ & $\begin{array}{l}8(3 \\
6 . \\
36 \\
\%)\end{array}$ & & & & & & & & \\
\hline $\begin{array}{l}\text { PSEUDO } \\
\text { MONAS } \\
\text { AERUGI } \\
\text { NOSA- } \\
4(8.3 \%)\end{array}$ & & $\begin{array}{l}4(1 \\
00 \\
\%)\end{array}$ & & & $\begin{array}{l}3(7 \\
5 \%)\end{array}$ & $\begin{array}{l}4(1 \\
00 \\
\%)\end{array}$ & & & $\begin{array}{l}1(2 \\
5 \% \\
)\end{array}$ & $\begin{array}{l}2(5 \\
0 \% \\
)\end{array}$ & $\begin{array}{l}4(1 \\
00 \\
\%)\end{array}$ & $\begin{array}{l}4(1 \\
00 \\
\%)\end{array}$ & $\begin{array}{l}1(2 \\
5 \% \\
)\end{array}$ & & & \\
\hline $\begin{array}{l}\text { KLEBSIE } \\
\text { LLA } \\
\text { PNEUM } \\
\text { ONIAE- } \\
10(20.8 \% \\
)\end{array}$ & $\begin{array}{l}4(40 \\
\%)\end{array}$ & $\begin{array}{l}10( \\
100 \\
\%)\end{array}$ & $\begin{array}{l}10( \\
100 \\
\%)\end{array}$ & $\begin{array}{l}10( \\
100 \\
\%)\end{array}$ & $\begin{array}{l}10( \\
100 \\
\%)\end{array}$ & $\begin{array}{l}10( \\
100 \\
\%)\end{array}$ & $\begin{array}{l}4(4 \\
0 \%)\end{array}$ & $\begin{array}{l}5(5 \\
0 \% \\
)\end{array}$ & & & & & & & & \\
\hline $\begin{array}{l}\text { STAPHY } \\
\text { LOCOC } \\
\text { CUS } \\
\text { AUREUS } \\
- \\
8(16.6 \%)\end{array}$ & $\begin{array}{l}6(75 \\
\%)\end{array}$ & $\begin{array}{l}4(5 \\
0 \%)\end{array}$ & & $\begin{array}{l}8(1 \\
00 \\
\%)\end{array}$ & & $\begin{array}{l}7(8 \\
7.5 \\
\%)\end{array}$ & $\begin{array}{l}3(3 \\
7.5 \\
\%)\end{array}$ & & & & & & & $\begin{array}{l}7(8 \\
7.5 \\
\%)\end{array}$ & $\begin{array}{l}6(7 \\
5 \% \\
)\end{array}$ & $\begin{array}{l}4(5 \\
0 \% \\
)\end{array}$ \\
\hline $\begin{array}{l}\text { CONS- } \\
4(8.3 \%)\end{array}$ & $\begin{array}{l}3(75 \\
\%)\end{array}$ & $\begin{array}{l}2(5 \\
0 \%)\end{array}$ & & $\begin{array}{l}4(1 \\
00 \\
\%)\end{array}$ & & $\begin{array}{l}4(1 \\
00 \\
\%)\end{array}$ & $\begin{array}{l}1(2 \\
5 \%)\end{array}$ & & & & & & & $\begin{array}{l}4(1 \\
00 \\
\%)\end{array}$ & $\begin{array}{l}3(7 \\
5 \% \\
)\end{array}$ & $\begin{array}{l}2(5 \\
0 \% \\
)\end{array}$ \\
\hline
\end{tabular}

Table :8- Antibiotic Sensitivity Pattern Of Both Gram Positive And Gram Negative Bacteria 
(AMC=30 mcg, CIP=5mcg, DO=30 mcg, AK=30 $\mathrm{mcg}, \quad \mathrm{G}=10 \mathrm{mcg}, \quad \mathrm{LE}=5 \mathrm{mcg}, \quad \mathrm{CTR}=30 \mathrm{mcg}, \quad \mathrm{COT}=25 \mathrm{mcg}$, CAZ=30mcg, CPM=30mcg, PIT=100/10 mcg, IPM=10 mcg, CTX=30 mcg, CX=30 mcg, CD=2 mcg, E=15 mcg).

\section{Discussion:-}

A total of 60 healthcare workers, which included 50 female nurses and10 male nurses, were included in this study, which were choosen randomly. Out of the 60 hand swabs samples analysed, 48 (80\%) yielded bacterial growth,while 12 (20\%) showed no bacterial growth.

Out of the 48 isolates, $36(75 \%)$ were all Gram negative, and 12(25\%) were gram positive organisms. Of 48 isolates, organisms were identified as 22( $45.8 \%)$ Escherichia coli, 4(8.3 \%) Pseudomonas aeruginosa, 10(20.8 \%) Klebsiella pneumoniae and 12 as Staphylococcus spp, of which 8(16.6\%) were Staphylococcus aureus and 4 (8.3 $\%)$ were Coagulase Negative Staphylococcu(CONS). Among the gram negative organisms, 16(72.72\%) ESBL producers were Escherichia coli and 6(60\%) ESBL producers were Klebsiella pneumoniae.Out of 8 S.aureus, 1(12.5\%) was MRSA. Among CONS, all of them were Methicillin sensitive.

This can be compared to a study carried out by Maheshwari et al.[7], which included $70 \mathrm{HCWs,} \mathrm{comparising}$ 20doctors, 20 nurses, 20 operation theatre (OT) technicians and 10 were laboratory technicians, from whom a total of 140 swabs were collected; and the organisms which were isolated were $S$. aureus in 13(18.6\%) and coagulase negative staphylococcus in $44(63 \%)$.

Out of 13, S. aureus isolates 6 (46.2\%) were MRSA. Gram negative bacteria (GNB) were isolated in 22(31.5\%), out of which $15(68.2 \%)$ were ESBL producers. Among the 15 ESBL producers,9 were Klebsiella pneumoniae, 5 were Escherichia coli and 1was Proteus mirabilis.

Sarfraz et al.[8] conducted a similar type of study ,comparising doctors and nurses of clinical department; and doctors and staff of non-clinical department .Organisms isolated were Staphylococcus aureus, Acinetobacterbaumannii, Pseudomonas aeruginosa, Coagulase negative Staphylococcus spp., Acinetobacterlwoffii, Escherichia coli and Corynebacterium spp., from hands of clinical staff (doctors + nurses). Organisms isolated from non-clinical staff was Acinetobacterlwoffii, Coagulase negative Staphylococcus spp., Staphylococcus aureus, Acinetobacter baumannii, Pseudomonas aeruginosa and Micrococcus spp.

SurvanaSande et al.[9], also showed in their study, a high rate of bacterial colonization in hand swab samples of HCWS , and proved the importance of hand washing, by showing very low rate of bacterial colonization in hand swab samples after hand washing. In there study, out of total 150 samples collected from Nursing staffs before hand washing, growth of microorganisms was observed in 107(71.3\%) samples and no growth in $43(28.7 \%)$ samples. No growth was obtained in $128(85.3 \%)$ samples and single type of growth in $22(14.7 \%)$ samples, after hand washing.

Of the 60 samples analyzed in our study, maximum samples showed growth of Escherichia coli. E. coli is Gramnegative, aerobic and facultative anaerobic bacteria [10].E. coli is an emerging nosocomial pathogen causing serious problems in health care settings[11].This species leads to both intestinal and extraintestinal infections in humans and many animals. Currently, six major groups of intestinal pathogenicE. coli (IPEC) have been recognized: enteropathogenicE. coli(EPEC), enteroaggregative E. coli (EAEC), Shiga toxin-producing E. coli (STEC), enterotoxigenic E. coli (ETEC), enteroinvasive E.coli(EIEC), and diffusely adherent E. coli (DAEC).

Three types of extraintestinal pathogenic E. coli(ExPEC) are also recognised, including neonatal meningitis-causing E. coli (NMEC),sepsis-causing E. coli (SEPEC), and uropathogenicE. coli (UPEC), associated with meningitis in newborns, systemic infections, and urinary tract infections (UTIs), respectively[12].

In our study, Escherichia coli showed 100\% sensitivity to Ciprofloxacin, Doxycycline, Amikacin, Gentamycin, Levofloxacin ;but were resistant to Amoxycillin/clavulanic acid(81.8\%), Ceftriaxone(72.7\%)

and Co-Trimoxazole(63.6\%).Total ESBL producers were $72.72 \%$.

Pseudomonas aeruginosa showed 100\% sensitivity to Ciprofloxacin, Levofloxacin, Piperacillin/Tazobactam, Imipenem; but were resistant to Ceftazidime(75\%), Cefepime(50\%), Gentamycin(25\%), Cefotaxime(75\%).

Klebsiella Pneumoniae showed $100 \%$ sensitivity to Ciprofloxacin, Doxycycline, Amikacin, Gentamycin, Levofloxacin ; but were resistant to Amoxycillin/ clavulanic acid(60\%), Ceftriaxone(60\%) and CoTrimoxazole(50\%). Total ESBL producers were $60 \%$. 
Staphylococcus aureus showed100\% sensitivity to Amikacin,(87.5\%) to Cefoxitin and Levofloxacin ,(75\%) to Amoxycillin/ clavulanic acid,(75\%) to Clindamyin,(50\%) to Erythromycin,(50\%)Ciproflaxacin, and least sensitive to Ceftriaxone( $37.5 \%)$. 1(12.5\%) was MRSA.

CONS were (100\% )sensitive to Cefoxitin, Amikacin, Levofloxacin;(75\%) to Amoxycillin/ clavulanic acid, Clindamyin;(50\%) to Erythromycin, Ciproflaxacin, and least sensitive to Ceftriaxone(25\%). All of the CONS were Methicillin sensitive.

In a study carried by Edem EN et al. [13], the antibiotic sensitivity pattern of the Staphylococcus aureus showed $60 \%$ to Oxacillin, $80 \%$ to Clindamycin, $43.3 \%$ to Erythromycin, $40 \%$ to Ceftriaxone, $77 \%$ to Ciprofloxacin, $23.3 \%$ to Trimethoprim Sulphamethoxazole and $73.3 \%$ to Amoxicillin clavulanic acid.13\% of the Staphylococcus aureus were found to inducible clindamycin resistant. The antibiotic sensitivity pattern of Staphylococcus epidermidis showed 56.2\%, 75\%, 19\%, 81.3\%, 12.5\% and 68.8\% to Erythromycin, Clindamycin, Ceftriaxone, Ciprofloxacin, Trimethoprim Sulphamethoxazole and Amoxicillin clavulanic acid, respectively. 6.25\% of the Staphylococcus epidermidis were found to be inducible Clindamycin resistant. Escherichia coli showed 100\% sensitivity to Ciprofloxacin, Ceftriaxone, , Gentamycin, Ceftazidime and Cefotaxime, but were resistant to Amoxicillin clavulanic acid and Cefpodoxime. It was non-ESBL producing. Proteus mirabilis showed 100\% sensitivity to Gentamycin, Ceftriaxone, Amoxicillin clavulanic acid and Cefotaxime. It was ESBL producing.

MRSA isolates showed 0\%, 50\%, 91\%, 33.3\% and75\% sensitivity to Oxacillin, Erythromycin, Clindamycin, Ceftriaxone, Ciprofloxacin, Trimethoprim Sulphamethoxazole and Amoxicillin clavulanic acid, respectively, and $16.6 \%$ of the MRSA isolates were inducible Clindamycin resistant.

Chaka et al. [14], in their study took samples from dominant hands of staff nurses, pediatric residents and medical interns and their cell phones. Staphylococcus aureus strains isolated from hand swabs were resistant to oxacillin, vancomycin and ceftazidime in $46 \%, 24 \%$ and $44 \%$ respectively. The resistance pattern of Staphylococcus aureus from cell phone isolates were $51.6 \%, 14 \%$ and $51 \%$ respectively for oxacillin, vancomycin and ceftazidime. CONS isolated were also resistant to commonlyprescribed antibiotics.

Kumar et al. [15] in their study showed that almost $25 \%$ of healthcare workers are stable nasal carriers and $30 \%$ $50 \%$ of them possess the bacteria in their hands. Tammelin et al. [16] also showed in their study that 50.7\% of healthcare workers carry bacteria in their nose and $26.3 \%$ in their hands.

Several studies have shown that most of the bacteria that cause nosocomial infections are those that have developed resistance to antibiotics used in treating those [17].

\section{Conclusion:-}

Since the group of individuals under this study were healthcare workers, their interaction and exposure to hospital environment could cause major risks in transmitting to hospital patients and spreading nosocomial infections.

So, by simple measure of hand washing, various infections can be controlled.

Healthcare workers should wash their hands regularly with antiseptic soap, or disinfect the hand by rubbing with alcohol solution.

\section{References:-}

1. Watutantrige R D A,Pakirisamy P,LumW S, and Xiaofen E C. A Study on Hand Contamination and HandWashing PracticesamongMedical Students. $\mathrm{J}$ of International Scholarly Research NetworkPublic Health2012: 1-5

2. Mani A,Shubangi A M,Saini R.Hand hygiene among health care workers.Indian J Dent Res 2010; 21(1):115118

3. Vivian O O, Esohe O. O, Rosemary A. O, Phebe O,OrezimenaO. Hand hygiene practices among doctors in a tertiaryhealth facility in southern Nigeria. J of Medicine in the Tropics 2013; 15(2):96-101

4. Alfred E. Y,Afua A. J. H. Hand hygiene practices and resources in a teaching hospital in Ghana. J Infect DevCtries2013;7(4):338-347

5. Mathai A S, George S E, Abraham J. Efficacy of a multimodal intervention strategy in

6. improving hand hygiene compliance in a tertiarylevel intensive care unit. Indian $\mathbf{J}$ of Critical Care Medicine 2011;15(1):6-15 
7. Mathur P. Hand hygiene: Back to the basics of infection control. Indian J Med Res 2011: 611-620

8. MaheshwariM,Devi L S, Agarwal P, Malhotra V L. Screening of Health Care Workers For Nasal And Hand Carriage of Multi-Drug Resistant Organisms in a Teaching Hospital in Rural Haryana, India. INTERNATIONAL J OF SCIENTIFIC RESEARCH 2014;3(11): 369-371

9. Sarfraz A, Bhattacharyya S, Ansari M A A, Jaiswal N K, Roy H, Kumar R, et al.

10. STUDY OF BACTERIAL FLORA OF HANDS OF HEALTH CARE GIVERS IN A TERTIARY CARE HOSPITAL IN EASTERN INDIA. J of Evolution of Med and Dent Sci 2015; 4( 27):4644-4648

11. Sande S, Basak S, Tawade V. EFFECT OF HAND WASHING AMONG NURSING STAFFS IN TERTIARY CARE HOSPITAL : A STUDY. Int J Cur Res Rev 2013;5 (24): 34-40

12. Ananthanarayan\&Paniker's. Enterobacteriaceai in textbook of Microbiology $9^{\text {th }}$ Ed,Universities Press Private Limited,Hyderabad,2013:274

13. Khan H A, Ahmad A, Mehboob R. Nosocomial infections and their control strategies. Asian Pac J Trop Biomed 2015; 5(7): 509-514

14. Toval F, Köhler C D, Vogel U, Wagenlehner F, Mellmann A, Fruth A et al. Characterization of Escherichia coli Isolates from Hospital Inpatients

15. or Outpatients with Urinary Tract Infection.J of Clinical Microbiology2014;52(2):407-418

16. Edem EN, Onwuezobe IA, Ochang EA, Etok CA and James IS. Antibiogram of Bacterial Isolates from the Anterior Nares and Hands of Health Care Workers in University of Uyo Teaching Hospital (UUTH) Uyo, Akwalbom State, Nigeria. J BacteriolParasitol 2013;4(2):1-5

17. Chaka T E, Misgana G M, Bogale W Fand Kassa R T. Bacterial Isolates from Cell Phones and Hands of Health Care Workers: A CrossSectional Study in Pediatric Wards at Black Lion Hospital, Addis Ababa,Ethiopia. J BacteriolParasitol 2016;7(4):1-6

18. Kumar P, Shukla I, Varshney S. Nasal screening of health care workers for nasal carriage of coagulase positive MRSA and prevalence of nasal colonization with Staphylococcus aureus. J of Biology and Medicine 2010;3:182-186

19. Tammelin A, Klotz F, Hambraeus A, Stahle E, Ransjo U. Nasal and hand carriage of Staphylococcus auerus in staff at a Department for Thoracic and Cardiovascular Surgery: Endogenous or Exogenous source? J of Infect Control HospEpidemiol2003;24:686-689

20. Farzana K, Rashid Z, Akhtar N, Sattar A, Khan JA et al. Nasal carriage of Staphylococci in health care workers: Antimicrobial susceptibility profile. Pak J Pharm Sci2008;21:290-294. 